\title{
How E-gov in Greece Affects Life-long Learning for Public Servants, Working on Technical Field
}

\author{
Dimitrios Goulas $^{1, *}$, Efthymios Valkanos ${ }^{2}$, Kassiani Droulia ${ }^{3}$ \\ ${ }^{1}$ Department of Computer Engineering, Municipality of Patras, Greece \\ ${ }^{2}$ Department of Educational and Social Policy, University of Macedonia, Greece \\ ${ }^{3}$ School of Humanities, Hellenic Open University, Greece
}

Copyright $\bigcirc 2016$ by authors, all rights reserved. Authors agree that this article remains permanently open access under the terms of the Creative Commons Attribution License 4.0 international License.

\begin{abstract}
Engineers that work as civil servants cover a wide range of competences, administrative and scientific, which implies that they deal with many difficulties in the exercise of their duties as executives. Electronic government (e-gov), through the use of new Technologies of Information and Communications (ICT) at public technical services, has changed the procedures and the daily operation of public services. These changes create new needs but also new prospects in education/training of public services' executives. In this research, authors made a case study, examining the case of the municipality of Patras, one of the bigger municipalities of Greece. They used the method of review and the quantitative methodological approach. Their objectives concentrated on recording the aspects of Engineers working as Public Employees, regarding new needs, possibilities and choices of training in the frames of e-gov and comparing their opinions with their appositeness and their role in the organization they serve.
\end{abstract}

Keywords Electronic Government, Non-typical Education, Engineers, Public Services, New Technologies

\section{Introduction}

Engineers that work as civil servants undertake the transaction of specialized and exigent work (studies, supervision and control of projects, control and approval of private sector studies, supervision of manufacturing of Public Sector and control of manufacturing of private projects), through a strict legislative frame.

They face a lot of problems in the exercise of their duties as administrative and scientific executives, charged with the production and the supervision of technical projects. Therefore, they have to combine theory with practice and study with appliance, facing many times specialized problems, concerning modern technology and techniques.

Moreover, the continuous changes in the sectors of Public
Administration and Local Self-government create new needs but also new prospects in education/training of their executives. The incorporation of new technologies in administrative processes and the appliance of e-gov create a new working frame for Public Employees, especially the engineers.

E-gov, according the definition of European Union [1], is defined as the use of information and communication technologies in public administrations combined with organisational change and new skills, in order to improve public services and democratic processes and to strengthen support to public policies.

Education in Greece is categorised to typical and non-typical. Typical is the education that is provided from educational structures of the National Educational System of Greece, including elementary schools, high schools, lyceums, technical educational institutes and universities. All the other organised programs which are provided by other structures consist of the non-typical education.

For the training of personnel, are organised, structures of non-typical education in Greece, including the National Centre of Public Administration and Self-government and its Institute of Training, the Centres of life-long Learning, the Centres of Professional Training, the Free Study Centres, etc.

The objectives of this research concentrated on recording the aspects of Engineers working as Public Employees, regarding needs, possibilities and choices of training in the frames of e-gov and comparing their opinions with their appositeness and their role in the organization they serve.

\section{Literature Review}

In the frame of appliance of e-Government and in order to keep up with other country members of EU [2], the last years Greece had made significant steps which have changed the way its public services work and especially the local self-government, which is represented by 
municipalities [3-5].

According the Greek Digital Strategy 2006-2013 [6], Greek Government had to boost till 2008 the growth of e-procurement, the broadband networks, the digital public services to citizens and businesses and the use of e-signature. Then, till 2013 Greece had to achieve the operation of one-stop servicing shops, the reform of organizations of public administration structures and the ICT incorporation to the educational system [7].

Before the economic crisis, there were many researches that noted problems in applying e-government at the Greek Municipalities (i.e. [8]) and delays [9].

The economic crisis that started from 2009, made Greece to use decentralization in order to make local self-government more efficient. To accomplish this, Greek government applied the Law 3852[10] "Kallikratis plan" reforming the local self-administration and its duties.

Even though the first "taste" was positive, authors couldn't deny the arrhythmias noted by the Central Union of Greek Municipalities and Communities [11]. Lack of resources led to the obligatory shrinkage of organizations of Municipalities but also led to the similarity in the confrontation in the way organizing and modernizing their structures, so that they correspond in the new electronic reality [12].

The Greek law 3979 [13] for Electronic Government, according the driving map for Electronic Government $[14,15]$, created a general frame for the application of e-gov to public administration.

This new electronic reality for public administration had to be adopted also by Public servants working on technical field. The working objects of Engineers in public administration cover a wide range of competences which are not bounded to the technical field([16-18] etc). There are several studies investigating the educational needs of adults $([19,22]$ or civil servants, generally or specifically, for concrete categories of employees and/or concrete services $[23,24]$. However they are not specialized in the particular category of engineers and the educational needs that arising from the application of e-gov.

According Ngai et al [25] the attitude of engineers toward e-learning -which, apart from exclusive e-learning, is included to the blended learning model-, is determined from the usability and usefulness. Basic success parameter of an educational program is also, according Selim [26], the characteristics of the trainee, as it is for example the sufficiency of his computer knowledge and the interactive collaboration, his attitude against active learning activities, etc. It is interesting to investigate training possibilities of engineers, by examining the existent training experience in training institutions on different learning models, the official briefing for training seminars of various forms (e-learning, face to face, blended), the possibilities of following-up of all learning models according the ICT knowledge, the available electronic equipment and the services' difficulties/obstacles.

It is important to examine for engineers their knowledge level on PC use and on ICT, and to compare it with the existent studies and the analysis in general for civil servants and ICT ([9,27-29] etc).

Even if, according to Daras et al [30], new technologies strengthen the motives for learning and communication and promote active learning, Shashaani [31] and Woodrow [32] proved that the degree of previous experience on PC influence their attitudes opposite and concretely: the interest, the confidence, the perceptible usefulness and the stereotypical behaviours. It worth therefore to examine how "electronic experience" influences the choices of engineers and examine ways to improve education using technology as Eggers [33] implies.

\section{Method}

In the research authors used the method of review, while a quantitative methodological approach is considered more suitable for the achievement of the objectives of the research. For the data collection was used an anonymous questionnaire. Authors included to it 25 questions separated in five units (A. Personal and educational data, B. Labour frame of engineers, C. Investigation of needs of training in the frames of e-gov, D. Investigation of possibilities of training in the frames of e-gov and $\mathrm{E}$. Investigation of choices of training in the frames of e-gov). They used mostly multiple choice questions and Likert measurement scale with 4 likely answers.

The population it concerns is all technicians that serve the Greek State. Because of the wide range of target population, was selected the case study on the target group of all specialties of engineers that work at the Municipality of Patras. The sample is constituted by $67 \%$ of all engineers working at the organisation of the municipality of Patras, distributed as it is shown at Figure 1, which is a satisfactory percentage of the target group in order to give representative and valid data and to export conclusions in this study safely. 


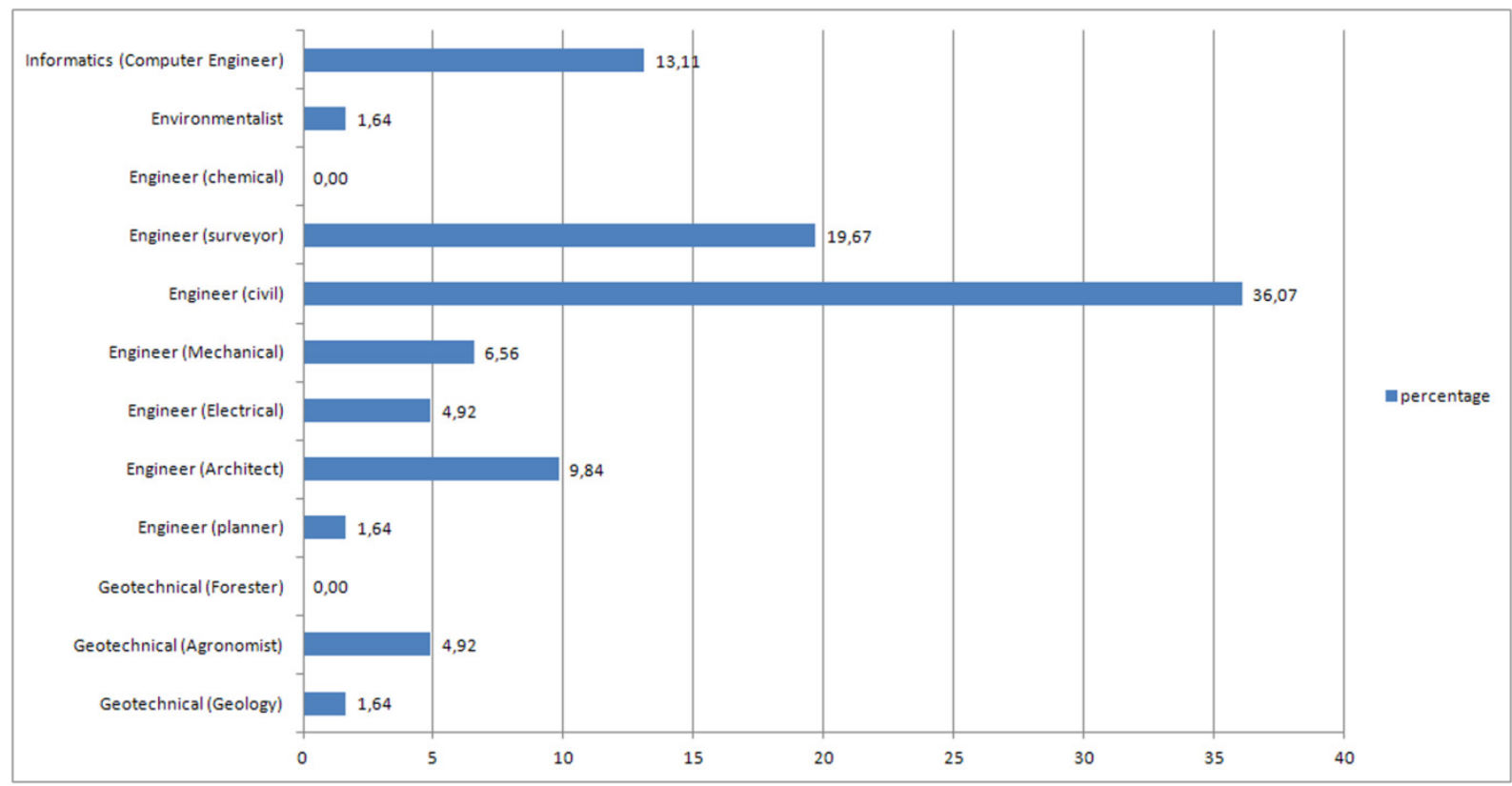

Figure 1. Percentage distribution of technical specialties of our sample at the municipality

The municipality of Patras is the third most populous municipality in Greece with more than 1.000 employees. Its organization has fully developed and organized technical services. As the largest municipality in population of the region of Western Greece, Patras provide the required support to other municipalities in the region that does not have the necessary infrastructure and appropriate staff for the exercise of their functions. The municipality of Patras was therefore considered a good case to study.

In addition, engineers in all the country apply the same rules and follow the same procedures for the planning and implementation of projects. Therefore changes related to eGovernment are applicable to all municipalities and all public services in Greece. Moreover, the largest number of engineers working as civil servants in Greece is employed in the municipalities. The Municipality of Patras has adequate staff with all the specialties of engineers. So, authors believe that engineers working at the municipality of Patras are a representative sample and the data obtained were not biased.

It should be mentioned however that each public service has its own particularities and its individual and/or redundant needs that it is impossible to be included in a case study. Authors' effort was focused in exporting conclusions that could be generalized corresponding to all state, leaned on the sincerity and the responsibility with which the sample answered the questions.

\section{Results and Discussion}

Authors interested for the ICT affection on life-long learning of a specific group: engineers working as public servants. Although engineers are occupied mainly on technical subjects, in this research was confirmed that they also deal with much work related with administration, research, legislation etc.

It is characteristic that most Engineers consider more important for the implementation of their duties the knowledge and continuous training on $\mathrm{PC}$ use and on specialized electronic programs -along with previous experience-. On the contrary, postgraduate studies were not considered significant from most engineers (82\%), concerning the implementation of their duties.

The most important reason for considering training necessary is the completion of knowledge on the practiced object and only few engineers $(7 \%)$ consider training unnecessary or consider it necessary only because they want to acquire specialization. That's because in public services the object of employment can change with certain internal locomotion, in order to satisfy certain administration needs. The objective of promotion (to head of department, director, or general director) constitutes an important motive for many engineers $(15 \%)$ for training because it gives bonus and develops dexterities which are appraised in the valuation.

Most engineers consider that legislation and subjects dealing with competences and technical/scientific subjects often need actualization of knowledge through training, while they show less interest for administrative subjects and subjects of EU co-financed programs.

Elaborating on ICT, engineers consider that there is small need for training on PC use. On the contrary, it is realized that the computerization of most of their work have made essential the knowledge and the training on specialized electronic programs, as shown at Figure 2. 


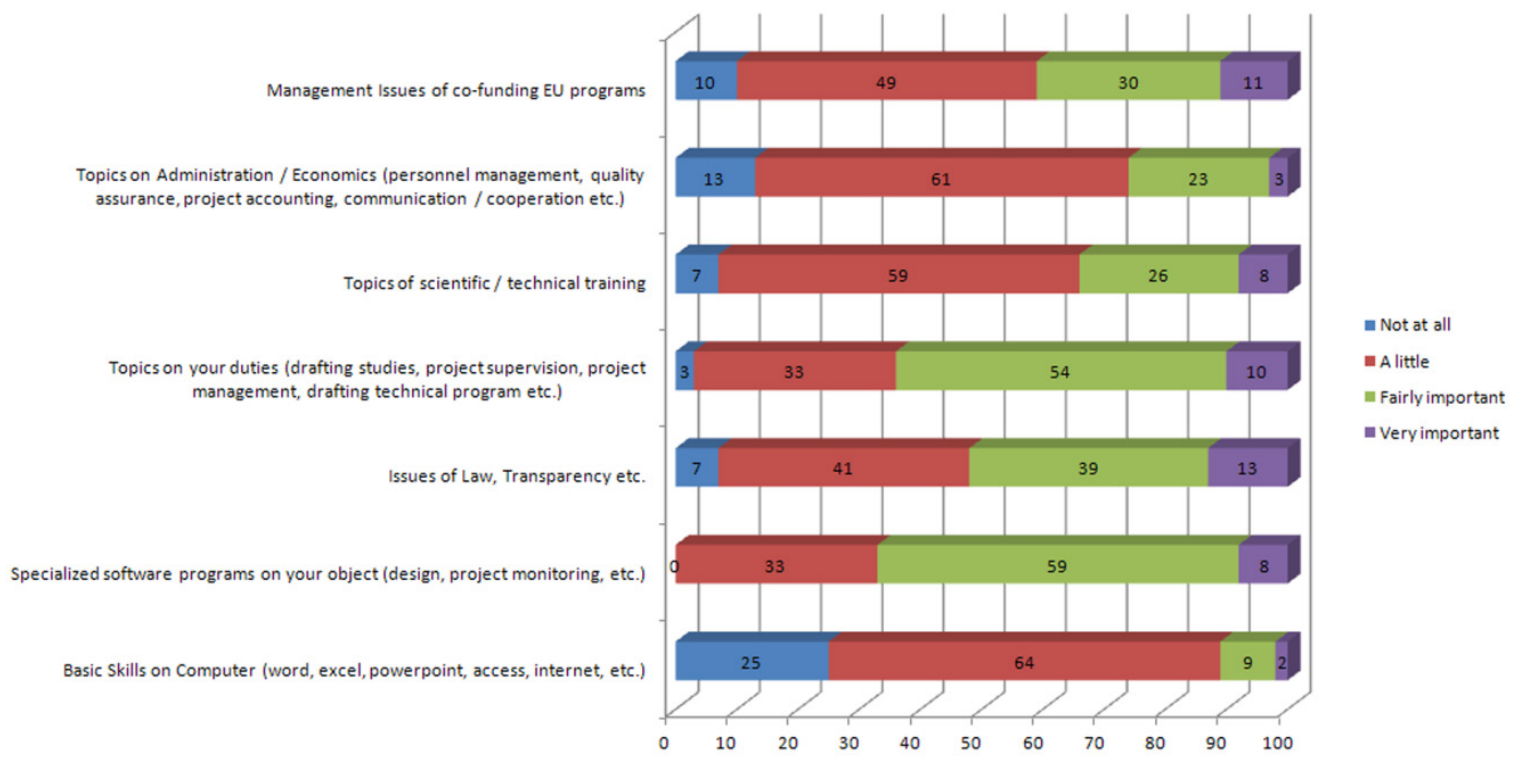

Figure 2. Percentage of Engineers' estimation on need for training

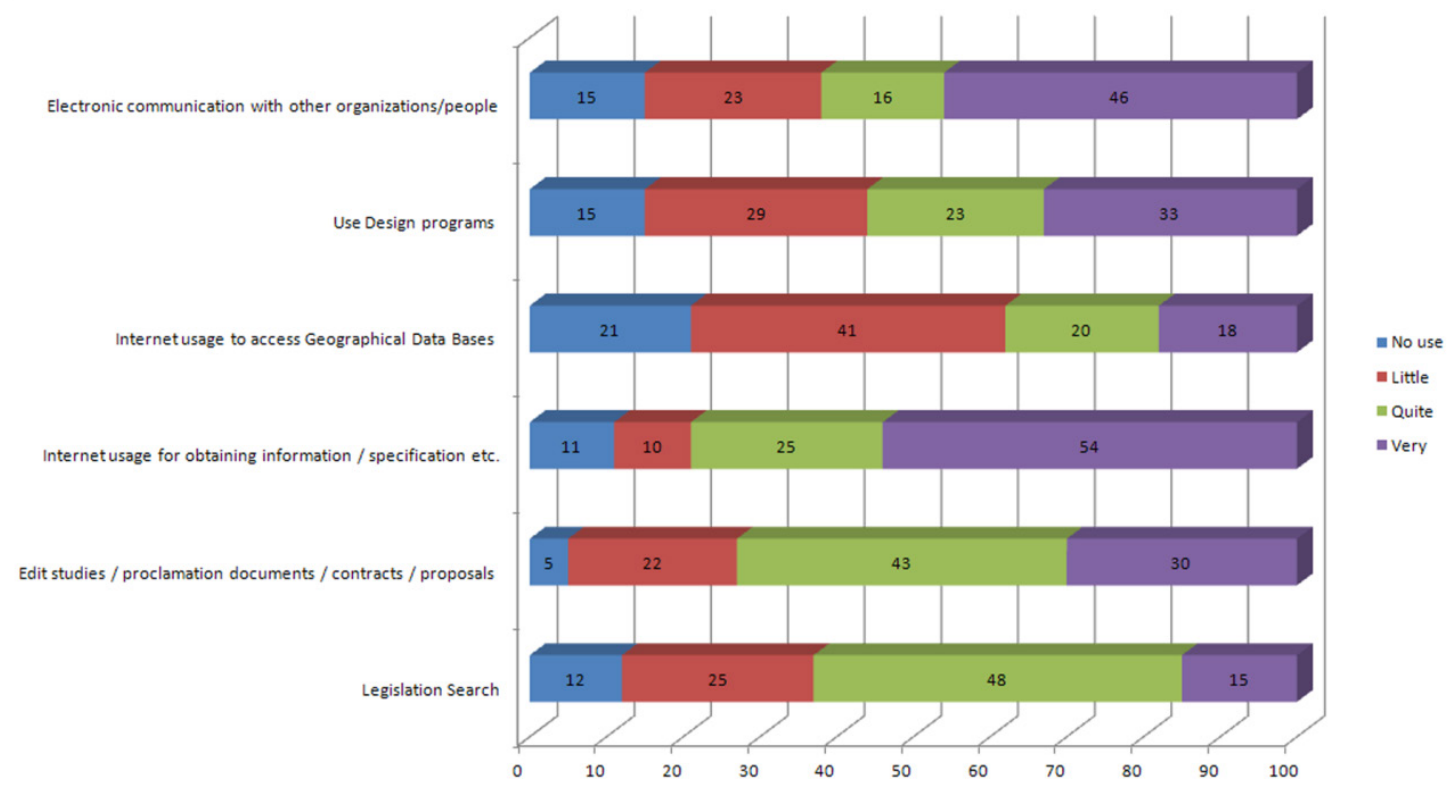

Figure 3. Percentage of engineers using PC for specific' work

Concerning the necessity of hardware/software for the implementation of their duties, most engineers consider essential the good use of computer and internet, while, depending on their competences and their specialties, they require concrete programs or internet access in concrete electronic libraries or Databases.

Almost all engineers in public sector use PC for writing/composing proposals/studies/conventions. Most of them use the computer for searching legislation, information/specifications and for electronic communication. Many engineers were using specialized applications and much less were those needed to connect to applications/web pages/Databases relative with their object (Figure 3).
Most engineers had the chance in the past and the experience of following-up training programs at the National Centre for Public Administration and Local Government - EKDDA (92\%). Other institutions that many engineers participated as trainees, are the universities/technological institutes (AEI/TEI), the Occupational Training/studies Centres (KEK/KES) and the Technical Occupational Chamber (TEE) with its educational institute IEKEM TEE. Few engineers were those that had participated in programs of life-long learning centres (KDBM) and no one had graduated from the National School of Public Administration and Local Government (ESDDA). The programs most engineers had participated were face to face programs and in most cases 
they have had self-training using handbooks/drivers etc. Just few Engineers had experience in programs of blended learning and fewer in entirely e-learning programs.

There must be noted that according the findings, public services do not inform their employees about the training choices they have, even if it is about seminars that are organized in regular base (e.g. seminars of EKDDA). Although the human resources' service of the Municipality is informed about, there's no vertical diffusion of information. Almost all Engineers of the Municipality, included those having posts of responsibility, are not informed, fact that creates doubts about the importance that is given to the training of employees by the self-government and the public administration in general.

As for internet services, all Engineers could use e-mail service for their work, least or more, as shown at Figure 4. However in advanced internet services and possibilities, the knowledge or the use level is very low. Most engineers are unfamiliar with services like newsgroup, real time chat/IRC, videoconference etc. Most of these services are used in e-learning and employees' weakness of use can constitute reason of exclusion from the possibility of following-up of corresponding programs.

Almost all Engineers use PC and high speed internet connections (see Figure 5). SYZEFXIS network and the Municipality investments in electronic/mechanical equipment in order to implement the digitalization of the provided services helped a lot to this. As it concerns e-learning equipment, external hardware was minimal. Only CD/DVD reader was available and functional in most of employees while speakers/earphones were available to half of them.

With regard to whether engineers have difficulties to participate to educational programs and for what reason, a big part of them (23\%) did not face any difficulties. For the remainder, authors denoted the difficulties finding suitable seminars and the pressure of work that did not allow engineers to deal with something else.

Employees' preference to the structure of EKDDA is obvious as the overwhelming majority preferred it for organizing and implementing their training. It seems that this preference is because of the fact that seminars of EKDDA give to public servants bonuses in promotions, while programs organized by other public institutions only help to the general improvement of their curriculum vitae. Moreover, EKDDA is a well-organized structure, adapting the needs of public institutions and employees.

As for the form of education engineers prefer, authors cannot export conclusions with objectivity, because the majority of Engineers did not have experience from two basic forms of education using ICT: blended (48\%) and e-learning (56\%). However there can safely be exported a conclusion regarding the face to face education and the self-education: In the majority, employees prefer them and are satisfied, having used both methods one or more times in their professional career.

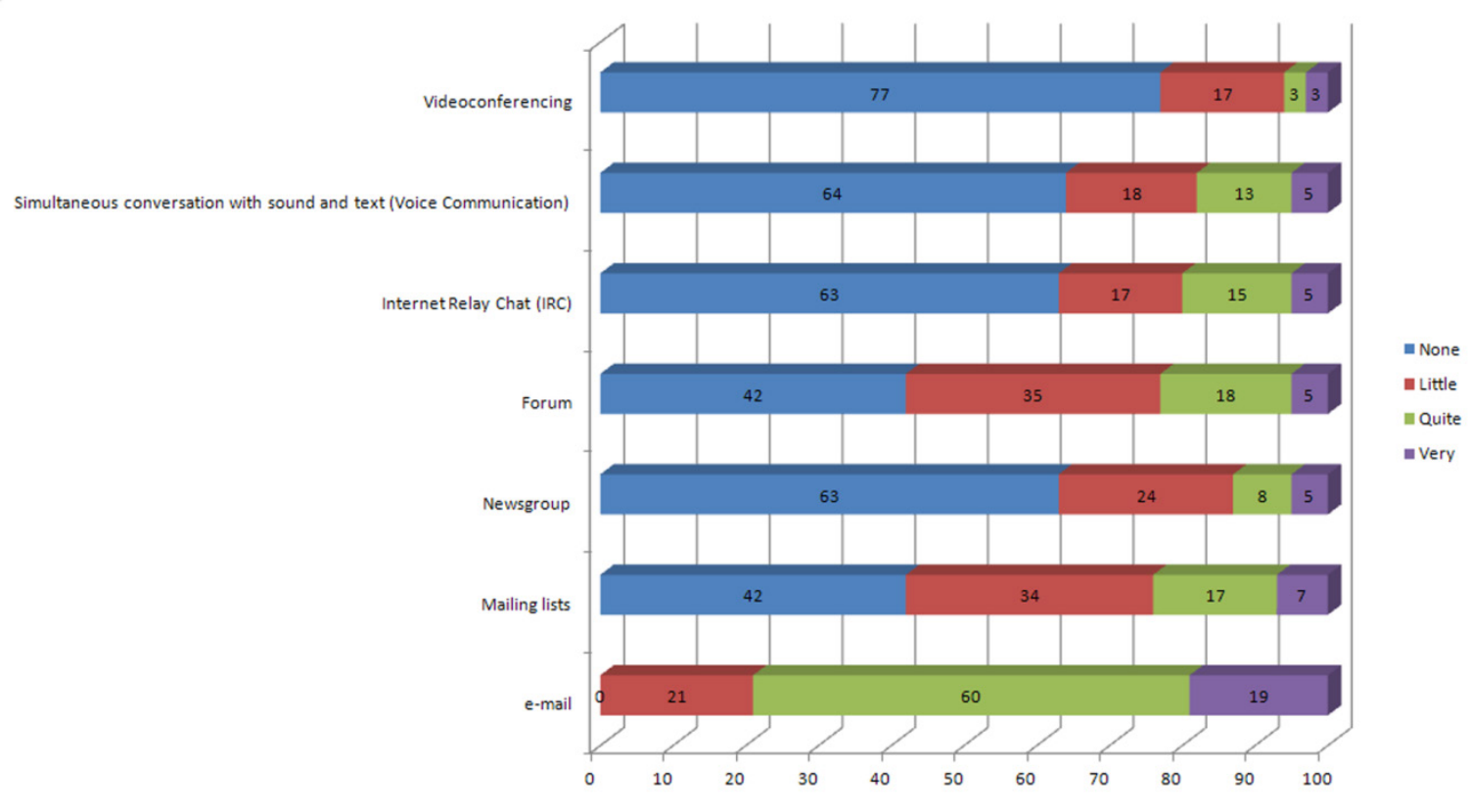

Figure 4. Percentage of engineers with specific abilities on using internet services 


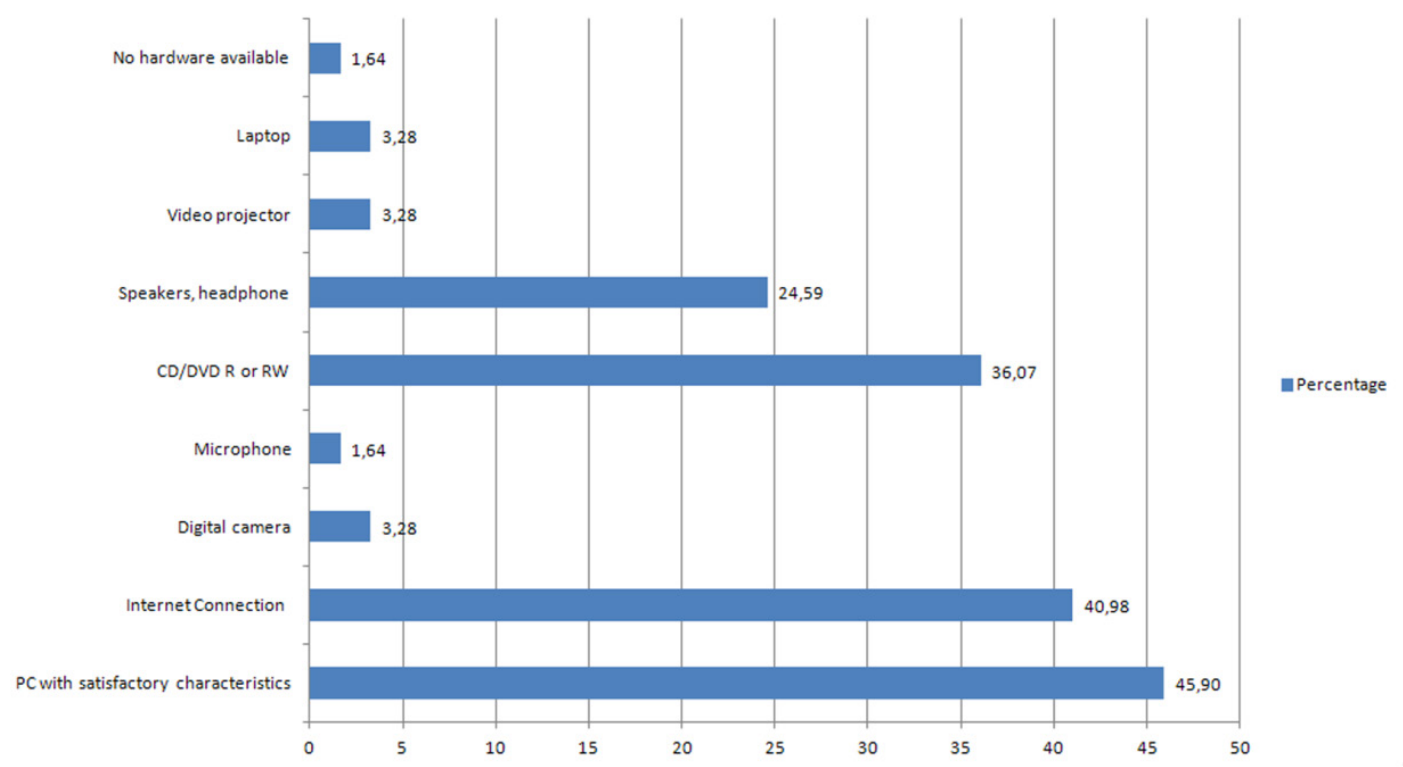

Figure 5. Percentage of engineers' using specific hardware

According the results, personal obligations do not leave engineers enough free time in order to spare it in training. Almost half of them (47\%) prefer programs that are implemented only at working hours. Maybe the work pressure does not allow them to participate in big duration programs because, in most cases, engineers prefer small duration programs (up to two weeks maximum). Few employees were not willing to participate in training programs, which is probably explained by the fact that these individuals were older, working on the same object for many years.

Even though for many Engineers (44\%) it is considered that there is no need for additional motives for participation, some of them pointed the need for official educational authorization for participating to programs relatively with their specialty but irrelevant with their current object of work. Few engineers asked additional bonus for promotion (perhaps because only training by concrete public institutions get bonus) while for some people is important to exist economic motives.

\section{Conclusions}

In this research was realized that training of Engineers is recognized and pointed out not only by the Greek State but also by the technical employees themselves. The academic knowledge an Engineer has, never suffice in order to cover his object diachronically. The processes continuously change, so as the legislation or even the object itself with which an engineer deals.

The entrance of new technologies in public administration and the appliance of e-gov, resulted in digitalization of most of the processes that Engineers follow and this has changed radically their way of work. Therefore, the research focused on the findings on ICT need on engineers' work, the technological background of public technical services and staff and the educational choices that can be met and conducted using ICT.

So, from this research authors resulted that almost all the competences of engineers are fulfilled henceforth with PC and internet use, with minimal exceptions. The knowledge of PC use is considered by engineers prerequisite and essential, in order to cope with their duties. In order an engineer to achieve the objectives that have been determined and to produce appreciable technical work, he should be able to communicate, coordinate and collaborate with other services of public and private sector, local self-governments and citizens [34] and this must be implemented electronically, as it is imposed by the current way of work.

It was obvious from the results of the research that is also considered essential for Engineers the knowledge of specialized computer programs, something that, certain employees -mainly oldest as it came out-, do not have to a satisfied degree. Moreover, many deficiencies exist, and engineers need to get constantly informed for the new electronic possibilities and the new software that is coming out in the market. The differentiations that were realized in the attitude of engineers toward PC, agree with Shashaani [31] and Woodrow [32] that implied that the degree of previous experience on PC influences powerfully their attitudes on training.

The results confirm older research of Goula \& Kontogeorga [8] that pointed out that the changes and the projects that are implemented for the appliance of e-gov, are not accompanied by suitable training of employees while concrete deficiencies and needs in the sector of ICT are recorded on this particular group of employees.

Training programs of non-typical education can become 
for the Greek State and the Self-government an important tool of actualization of knowledge of their technical personnel and improve the provided technical services' effectiveness. As it was seen in this research, the various Greek institutions of non-typical education that provide training to civil servants are familiar to engineers and various training programs have organized and developed, financed many times from EU.

Authors realized that the new models of learning that utilize ICT, blended or e-learning, are not enough propagated to engineers. This is probably because of the small number of programs that is organized and implemented with these models but also because of lacks of ICT knowledge and equipment that is required in order to be able somebody to participate. The results of this research show, in agreement with Selim [26], that the level of knowledge and experience that employees have in internet services, are limited in the fields of basic internet services and the basic internet tools. Moreover the equipment is limited in the basic I/O digital devices and lacks in tools such as microphone, camera etc. that would facilitate e-learning.

The administrations, as was realized, do not inform employees for the organized training programs of all forms that could concern them. However, with the application of organizational structures to reform public administration, are created today specialized services that deal specifically with employees' training. This fact confirm the lack that has been realized by the government and the need for organizing training, taking into account employees' opinions -including engineers- while one basic rule at adults' education is the activation and the entanglement of trainees in all phases of the educational process [35].

About the difficulties engineers face, appeared that the pressure of work does not give them the ability to follow-up training programs, while the need for locomotion or the requirement of concrete ICT equipment creates moreover impediments, especially when the seminars are few and concrete. Most important however is the lack of suitable programs that would cover the needs that engineers have.

It was obvious from the results that engineers and probably the remainder employees, prefer to participate in training programs organized by EKDDA. This is justified while it is an institution with well-organized structure, which is addressed exclusively to civil servants, with many specialized seminars which have been organized in collaboration with their trade-unions. Important difference from the remainder institutions of non-typical education (universities, TEIs, IEKEM TEE, KEK/KES, KDBM etc.) is also that others' programs are addressed to a wider group, while certification of the programs of EKDDA enjoys of recognition by the state (bonus in promotions, etc.), according the Greek Law 3839/2010.

The lack of experience in alternative training forms which are using ICT by the majority of Engineers could not give to authors the information that was needed, in order to evaluate the preference of certain training forms regarding others. However, there was distinguished a positive attitude of engineers toward the learning models that include e-learning part, something that confirms also the conclusions of researchers Daras et al. [30] and Bhuasiri et al. [36] observing that trainees are positive in the possibilities ICT give in education. As Liaw et al. [37] noticed, the positive attitude of trainees leads to their bigger intention of attendance to training programs and helps to the effective application of e-learning.

The big pressure of work that technical services have, in many cases does not give Engineers the possibility to spare time for their training. In combination with other obligations, apart from those in their working time [20], engineers' services must ensure the requisite time and means so they could participate in training. This is probably the reason that smaller duration programs are preferred, while it is easier for public services to permit their employees to participate.

Training programs for which are not given from their engineers' services any motives are not preferred, although they can be more relevant with their specialty and their special needs. So their choices are related to the motives provided to them. Of course, certification of training is a basic motive, but being the basic motive can lead to passive attendance and lack of real interest. Training is not only for increasing typical qualifications and building better CV. So, there is a risk for employees to prefer seminars with typical validity, in order to get bonus for promotion and to participate in general and vague programs instead other that are more concrete and useful. However, the certification and the way that it is obtained is surely a criterion of the quality of training and the same goes for the institution that implements it.

Moreover, it is required essential state intervention and aid to institutions organizing training programs and also promotion of the attendance and the interest of public administration's technical personnel through the improvement and the enrichment of the provided motives. With the exploitation of motives that exist and that each service can give, the personnel of technical services might be upgraded qualitatively and this can have respectively results and in the produced work.

Concluding, most Engineers -occupied in public administration- are permanent employees and much less are the private-law legal persons (I.D.A.X.). Considering the way of engagements (via the Supreme Council for Civil Personnel Selection A.S.E.P.) and the restriction of engagements in Greece the last 5 years, almost all employees-engineers have many years of previous experience, in private or public sector. Technical services in Greece are staffed by engineers of many specialties in order to cover all breadth of appositeness of the services, which agrees with the conclusions of the research of TEE [18]. Also, many engineers, because of their high qualifications, have occasionally practiced duties in different posts of 
responsibility. Authors confirmed researches [16,17] about Engineers' complex role and objects in the State, which cover a wide range of competences that is not limited to the technical part.

Therefore, for their better response on their duties, according to the opinions that were recorded, important role have the previous experience and the experience they have acquired, but equally considerably are considered are the continuous training and the ICT knowledge on PC use and specialized electronic programs. The postgraduate specialization via the acquisition of a postgraduate or doctoral title can be essential only in the case it is exactly on their object of employment. In general, it is realized that ICT have changed radically the operation of technical services and have been adapted in the new era, mostly by younger engineers. The turn to ICT use and the recognition of the importance of continuous training by Engineers agrees with Ngai et al [25].

\section{REFERENCES}

[1] European Commission. The Role of eGovernment for Europe's Future, Brussels, 2003.

[2] Szilárd, M. eGovernment in the European Union, publication of coursebook supported by European Commission DG Education and Culture, via the Leonardo da Vincu and NETIS programmes, Budapest, 2007.

[3] European Commission, (2014). eGovernment factsheets in Greece, Edition 16.0. Retrieved December 01, 2015, from http://joinup.ec.europa.eu/sites/default/files/c5/1c/69/eGov\% 20in\%20GR\%20-\%20April\%2014\%20-\%20v.16.pdf.

[4] OECD, (2013). Government at a glance, Factsheet for Greece. Retrieved August 30, 2013, fromhttp://www.oecd.org/gov/G AAG2013_CFS_GRC.pdf

[5] Leijenaar, R. D. The impact of e-government on the organization of local authorities, 6th Twente Student Conference on IT, University of Twente, Netherlands, 2007.

[6] Greek Special Secretary for Digital Planning, (2006). Digital Strategy 2006-2013. Retrieved January 06, 2016, from http://www.infosoc.gr/NR/rdonlyres/A13F889F-DE92-4DC F-B64A-37351BFC69B9/3053/ktp_all.pdf.

[7] European Commission, (2005). "i2010 - A European Information Society for growth and employment", Information Society. Retrieved October 14, 2015, from http://eur-lex.europa.eu/LexUriServ/LexUriServ.do?uri=CO M:2005:0229:FIN:EN:PD.

[8] Goulas, D., Kontogeorga, G. E-government appliance problems on first degree self-government of Greece, Euromedia 2009, 15th Annual Scientific Conference, Bruges, Belgium, 2009

[9] Hahamis, P., Iles, J., Healy, M. e-Government in Greece: Bridging the gap Between Need and Reality, University of Westminster, London UK, 2005.

[10] Law 3852/2010. New Architecture of Government and
Decentralized Administration-Kallikratis plan, Athens, National Press, 2010.

[11] Central Union of Greek Municipalities and Communities. «First test positive but many arrhythmias», Inspection of Local Government, Issue 130, Athens, pp. 37, Multimedia Computer Applications S.A, 2011.

[12] Goulas D., Kontogeorga G. How did the economic crisis in Greece affected the steps in applying e-government at the first degree self-government of Greece, Journal of Governance and Regulation / Volume 2, Issue 4, 2013.

[13] Law 3979/2011. Electronic Government, Athens, National Press, 2011.

[14] Planning group for the Roadmap for eGovernment, (2011). Roadmap for eGovernment. Ministry of Administrative Reform and E-Government, Greece. Retrieved January 01, 2015, from

http://www.ictplus.gr/files/1_TELECOM_STRATEGIES/PS ALIDAS MICHALIS 270711.pdf

[15] Anthopoulos, G. L. \& Reddick, G. C. Government e-Strategic Planning and Management: Practices, Patterns and Roadmaps, Springer, USA, 2014.

[16] Katikas, P. (2005). The role of public Technical Services Policies and actions now and in the future. 1st European Conference "The role and the work of engineers public employees", Athens, 9-11/6/2005. http://www.emdydas.gr. Accessed 22 Nov 2013

[17] Romosios, Al. Upgrade of monitoring and control of public projects, Meeting for "Administrative reform - the technical services and engineers as lever of growth", Athens, 2012.

[18] TEE, (2009). Research on the professional situation and employment of engineers, Retrieved October 30, 2013, from http://portal.tee.gr/portal/page/portal/PROFESSIONAL ISS UES/neoi_mixanikoi/Tab5230282:Tab3

[19] Cross, K. P. Adults as Learners. San Francisco: Jossey-Bass, 1981.

[20] Darkenwald, G., Valentine, T. Deterrents to participation in adult education: profiles of potential learners. Adult Education Quarterly 34 (2), 1990.

[21] Courau, S. The basic tools of instructor of adults. Athens: Metaixmio Press, 2000.

[22] Hornik, S., Johnson, R. D., Wu, Y. When technology does not support learning: Conflicts between epistemological beliefs and technology support in virtual learning environments. Journal of Organizational and End User Computing, 19(2), 23-46, 2007.

[23] E.K.D.D.A. System of detection of educational needs for the Public Administration. Athens: E.K.D.D.A., 2003.

[24] Kokkos, A. Education of Adults: detecting the field. Athens: Metaixmio Press, 2005.

[25] Ngai, E. W. T. , Poon, J. K. L., Chan, Y. H. C. Empirical examination of the adoption of WebCT using TAM. Computers \& Education. 48(2), 250-267, 2007.

[26] Selim, H. M. Critical success factors for e-learning acceptance: confirmatory factor models. Computers \& Education. 49(2), 396-413, 2007. 
[27] Antona, M. e-Government country report for GREECE, Ministry of Economy \& Finance/National Coordination Authority, EYऽ/YПOIO, 2008.

[28] Goulas, D. .Applying e-gov to the Greek municipalities: a case study in the region of Western Greece, LAP Lambert Academic Publishing, 2013.

[29] Andronopoylos, V. Municipalities and prefectures in front of the digital government, General Secretariat of Public Administration and Electronic Government, Athens, 2007.

[30] Daras, T., Stamouli, M. A., Apostolakis I. Attitudes and behaviors of health staff for distance learning education, 5th International Conference in Open \& Distance Learning November 2009. Athens, Greece, 2009.

[31] Shashaani, L. Gender-differences in computer experience and its influence on computer attitudes. Journal of Educational Computing Research, 11, 347-367, 1994.

[32] Woodrow, J. E. J. The development of computer-related attitudes of secondary students. Journal of Educational Computing Research. 11(4), 307-338, 1994.
[33] Eggers, W. D. Government 2.0: Using technology to improve education, cut red tape, reduce gridlock and enhance democracy. Lanham: Rowman and Littlefield Publishers Inc, 2005.

[34] NAE (National Academy of Engineering). Educating the engineer of 2020: adapting engineering education to the New Century. Washington DC, USA: The National Academic Press, 2005.

[35] Rogers, A. Adults' Education (int. Papadopoulou M. and Tomprou M.). Athens: Metaixmio Press, 1999.

[36] Bhuasiri, W., Xaymoungkhoun, O., Zo, H., Rho, J. J., Ciganek, A. P. Critical success factors for e-learning in developing countries: A comparative analysis between ICT experts and faculty. Computers \& Education 58 843-855, 2012.

[37] Liaw, S. S., Chang, W. C., Hung, W. H., Huang, H. M. Attitudes toward search engines as a learning assisted tool: approach of Liaw and Huang's research model. Computers in Human Behavior. 22, 177-190, 2006. 